\title{
Transatlantic Perspectives on Partnership Law: Risk and Instability
}

\author{
Deborah A. DeMott ${ }^{*}$
}

I. INTRODUCTION

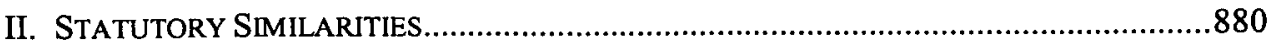

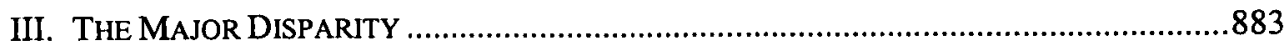

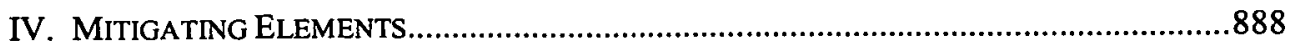

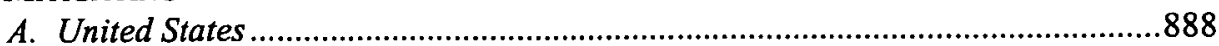

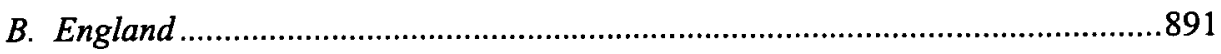

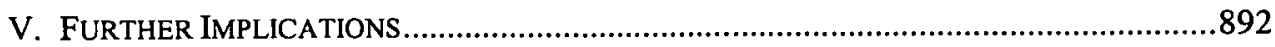

\section{INTRODUCTION}

General partnership law in the United States, although comparable to English law in many respects, has long differed on a fundamental question: If a partner wishes to terminate membership in a partnership, is the partner bound by a prior agreement to remain a member of the partnership? Different answers to this basic question carry corollary consequences for other provisions within partnership legislation. These differences have persisted through the twentieth century and remain evident in contemporary partnership legislation in the United States as contrasted with the reform alternatives for English partnership law presented recently by the Law Commissions in their Consultation Paper on Partnership (Consultation Paper). ${ }^{1}$ The thesis of this Article is that partnership legislation in each country strikes a different balance in the inevitable trade-offs between stability for the partnership association and risk as perceived by each individual partner. These trade-offs make the general partnership in the United States less stable as a form of business association, but also reduce certain risks otherwise borne by individual partners.

The law applicable to general partnerships is a rich source of legal puzzles because the underlying concepts draw on doctrine from contract, agency, and property, and do so in ways that reveal tensions among them. In particular, elements of partnership law drawn from contract law may be at odds with partnership's inclusion of elements drawn

* David F. Cavers Professor of Law, Duke University School of Law; Centennial Professor, Law Department, London School of Economics and Political Science. This Article is based on a public lecture given at the Institute for Advanced Legal Studies, London, March 2001. I am grateful to the audience, and to Professors Evelyn Brody, Paul Davies, and Judith Freedman, for comments and suggestions.

1. LAW COMM'N \& SCOTTISH LaW COMM'N, PARTNERShip LaW: A JONT CONSUltation PaPER (2000). Throughout this Article, references are to "English" partnership law. The intention is to exclude any reference to the Scottish law of partnership. Partnership law in England and Wales differs materially from Scottish law. See id. at 8-9. 
from the common law of agency. Different elements dominate partnership law in England compared with the United States. This Article begins by discussing the basic similarities in partnership law in the two countries, ${ }^{2}$ followed by the major difference. ${ }^{3}$ The Article then examines the consequences that follow from this difference and identifies points on which further empirical research would be illuminating. ${ }^{4}$

Before examining the legal specifics, consider as an initial matter an analogy or visual metaphor. The points of partnership law examined in this Article involve what may be termed architectural features or choices-basic decisions concerning the structure of the relationship among parties and their rights and powers as defined in large measure by the statute applicable to a particular type of business association. Architectural features in the law of business associations have consequences that pervade the particular body of law and explain many of its specific provisions. By analogy, an architect designing a vaulted building, at least one capable of standing for any appreciable time, develops a design that counteracts the forces of compression and tension that push downward and pull outward on the vault. Unsuccessful vaulted buildings fail to play compression and tension off against each other and channel these forces safely to the ground. Designs for successful vaults - like the Pantheon and the domed cathedral in Florence-can span vast spaces, but the design's solution to the basic problem tends to implicate many other visual and functional elements in the building. ${ }^{5}$ For example, the coffers in the ceiling of the Pantheon's dome, a memorable visual feature, also lighten the load that the dome imposes. Likewise, the law applicable to any particular form of business association reflects a series of choices-whether made explicitly or implicitly-about basic structural questions; consequences of these basic choices are diffused throughout applicable law.

\section{STATUTORY SimilarITIES}

To place the differences between English and U.S. partnership law in context, it is important to begin by identifying common features of general partnership law in the two countries. In both countries, general partnership legislation covers the same subjectmatter. In England, partnership is defined in section 1(1) of the Partnership Act of 1890 as "the relation which subsists between persons carrying on a business in common with a view to profit."6 The counterpart definition in U.S. legislation characterizes a partnership as an "association" and partners as "co-owners" who carry on a business for profit. These definitions do not differ materially in the subject-matter covered by partnership law. ${ }^{7}$

2. See infra Part II.

3. See infra Part III.

4. See infra Parts IV-V.

5. ROSS KING, BRUNELlESCHI'S DOME: HOW A RENAISSANCE GENIUS REINVENTED ARCHITECTURE 28 $31(2000)$.

6. Partnership Act, 1890,53 \& 54 Vict., c. 39, § 1(1) (Eng.).

7. The Uniform Partnership Act of 1914 (UPA) defines a partnership in section 6(1) as "an association of two or more persons to carry on as co-owners a business for profit." UNIF. P'SHIP ACT $\S 6(1)$ (1914), 6 U.L.A. 56 (1995). Under section 202(a) of the Revised Uniform Partnership Act of 1997 (RUPA), "the association of two or more persons to carry on as co-owners a business for profit forms a partnership, whether or not the persons intend to form a partnership." REV. UNIF. P'SHIP ACT $\S 202(a)$ (amended 1997), 6 U.L.A. 56 (Supp. 2001). 
Similarly, both countries' legislation contains provisions comparable in substance that exclude from the scope of the general definition of partnership certain relationships in which a person receives a share in the profits of a business, such as repayment of a loan in amounts that vary with the profitability of a business. However, such a person is not to be treated as a partner. ${ }^{8}$ Moreover, in both countries partners in a general partnership are its agents and as such hold power to bind the firm. In the words of the Partnership Act of 1890 , a partnership is bound by "any act for carrying on in the usual way business of the kind carried on by the firm ... unless the partner so acting has in fact no authority ... and the person with whom he is dealing either knows that he has no authority, or does not know or believe him to be a partner." Finally, in both countries general partners have

One consequence of characterizing partnership as a "relation" as opposed to an "association" is the need for additional terminology. Section 4(1) in the Partnership Act of 1890 provides that "[p]ersons who have entered into partnership with each other are for purposes of this Act called collectively a firm, and the name under which their business is carried on is called the firm-name." Partnership Act, 1890, 53 \& 54 Vict., c. 39, $\S$ 4(1) (Eng.). In contrast, the UPA and RUPA do not use the "firm" terminology.

8. See Partnership Act, 1890,53 \& 54, c. 39, $\$ 2$ (Eng.); UNIF. P'SHIP ACT $\$ 7$ (1914), 6 U.L.A. 280 (1995); REV. UNIF. P'SHIP ACT $\S 202$ (c) (amended 1997), 6 U.L.A. 56 (Supp. 2001).

9. Partnership Act, 1890,53 \& 54 Vict., c. 39, $\$ 5$ (Eng.). Under the Partnership Act of 1890, a partner is an agent of fellow partners as well as an agent of the firm. Id. In contrast, the UPA and RUPA characterize a partner as an agent only of "the partnership." UNIF. P'SHIP ACT $\S 9$ (1914), 6 U.L.A. 400 (1995); REV. UNIF. P'SHIP ACT § 301(1) (amended 1997), 6 U.L.A. 60 (Supp. 2001). Thus, partners in partnerships subject to U.S. law are not each other's "mutual agents" although they may be individually liable for obligations of the partnership that fellow partners have incurred. Moreover, in both jurisdictions, a partner who wishes to "revoke" the authority of her fellow partners may do so only by dissolving the partnership or disassociating from it, a step that carries many complex consequences and that English law limits to partnerships at will. In contrast with the common law of agency, a partner's manifestation of intent to revoke a fellow partner's authority is ineffective. See RESTATEMENT (THIRD) OF AGENCY $\$ 3.10$ (Tentative Draft No. 2, 2001).

The U.S. legislation makes a partner's apparent authority dependent upon the scope of the partnership business and does not additionally condition it on whether the third-party knew or believed the actor to be a partner. See UNIF. P'SHIP ACT § 9 (1914), 6 U.L.A. 400-01 (1995).

(1) Every partmer is an agent of the partnership for the purpose of its business, and the act of every partner ... for apparently carrying on in the usual way the business of the partnership of which he is a member binds the partnership, unless the partner so acting has in fact no authority to act for the partnership in the particular matter, and the person with whom he is dealing has knowledge of the fact that he has no such authority.

(2) An act of a partner which is not apparently for the carrying on of the business of the partnership in the usual way does not bind the partnership unless authorized by the other partners.

Id. Sections 301(1) and (2) of RUPA are comparable, except in two respects. Section 301(1) makes explicit that a partner's apparent authority includes acts for carrying on in the ordinary course "business of the kind carried on by the partnership," not just a partnership's particular business. REV. UNIF. P'SHIP ACT $§ 301(1)(1994), 6$ U.L.A. 33 (1995) (emphasis added). Section 301(2) permits a partnership to limit the risk created by unauthorized acts by providing a notification to a third party that states the restrictions imposed on a partner's authority. REV. UNIF. P'SHIP ACT § 301(2) (1994), 6 U.L.A. 33-34 (1995). RUPA section 102(d) provides that a notification is effective upon its delivery to a person's place of business or other place that the person designates to receive communications. Id. $\S 102$ (d) (1994), 6 U.L.A. 43 (1995). The point is to make the effectiveness of restrictions on authority independent of a showing of actual knowledge. See id. $\S 102$ official cmt. 3, 6 U.L.A. 43 (1995).

In contrast, the last part of section 5 in the Partnership Act of 1890 carries the implication that if a third party who does not know that the person with whom dealing occur is a member of a partnership, fellow partners are not liable for the obligation resulting from the partner's dealings with the third party. If so, section 
individual liability for obligations incurred by the partnership. ${ }^{10}$ This is commonly treated as a fundamental and defining element of a general partnership. Indeed, the drafter of the 1914 uniform partnership legislation in the United States, William Draper Lewis, wrote that the element of individual liability is "the idea of every business man who deals with a partnership, that he is dealing with a group of persons who are directly and unlimitedly liable for partnership obligations."11

A brief historical note may help here. The 1914 statute was highly successful; almost every state enacted legislation closely patterned on it. ${ }^{12}$ This made partnership law less susceptible to state-by-state variation than other bodies of law, such as corporate law. The effect of the 1914 statute was long-lived as well. The early 1990 s saw the completion of the Revised Uniform Partnership Act (RUPA), now the basis for legislation in many states, some embodying significant departures from the proposed uniform provisions. ${ }^{13}$

The original project that culminated in the 1914 uniform legislation did not have an entirely auspicious beginning. The first drafter, James Barr Ames, died mid-way into the project. Sad enough in itself, but his underlying theory, as well as his draft, diverged markedly from what appear to have been Lewis's views. As the language just quoted may imply, Lewis was committed to the view that a general partnership is necessarily an aggregate of discrete persons as opposed to an entity having a distinct juridical personality. Ames, in contrast, was a proponent of treating general partnerships as legal entities distinct from their members. Following Ames's death, and Lewis's appointment as his successor, Lewis gave advisers to the project two alternative drafts from which to choose, one drawn on the entity premise and the other on the aggregate premise. The advisors sided with Lewis, perhaps persuaded by his argument that it would, at the least, be cumbersome to explain how partners can have individual liability (a proposition to which Ames was also committed) when a third party has acquired rights and liabilities that in the first instance bind the partnership as an entity. ${ }^{14}$ Almost a century later, RUPA

5 rejects the common-law doctrine of the undisclosed principal, as stated and applied in Watteau v. Fenwick. 1 Q.B. 346 (1893). For discussion of alternative interpretations of section 5, along with cases and commentary supportive of applying undisclosed principal doctrine in this context, see GEOFFREY MORSE, PARTNERSHIP LAW 86-89 (4th ed. 1998).

10. See Partnership Act, 1890, 53 \& 54 Vict., c. 39, $\$ 9$ (Eng.); UNIF. P'sHIP ACT. $\$ 15$ (1914), 6 U.L.A. 456 (1995); REV. UNIF. P'SHIP ACT §306(a) (amended 1997), 6 U.L.A. 69 (Supp. 2001).

11. William D. Lewis, The Uniform Partnership Act, 24 YALE L.J. 617,641 (1915). Cf. Allen W. Vestal, "... Drawing Near the Fastness?"-The Failed United States Experiment in Unincorporated Business Entity Reform, 26 J. CORP. L. 1019, 1029 (2001). Vestal notes that a decade of changes produced:

a widening gap between the popular conception of the partnership relationship and the legal restatement of the concept. It is my sense that the popular conception of the partnership relationship is much closer to the tort-based, relationship-driven model under the UPA and the Id. common law than it is to the contract-based, immediate self-interest model under RUPA.

12. The sole exception is Louisiana. The Civil Code defines a partnership as "a juridical person, distinct from its partners, created by a contract between two or more persons to combine their efforts or resources in determined proportions and to collaborate at mutual risk for their common profit or commercial benefit." LA. CrV. CODE ANN. art. 2801 (2001).

13. For instances of non-uniform provisions in states that have otherwise adopted RUPA, see Vestal, supra note 11 , at 1027-28 $\mathrm{nn} .55-67$ and accompanying text.

14. See Lewis, supra note 11, at 640-41. Lewis wrote that the entity theory, "while it enables us to solve the rights of the separate judgment creditor of a partner in the partnership property, it makes it impossible to 
overcame this particular problem by distinguishing between primary and secondary liability. RUPA provides that a partnership creditor may not levy execution against the individual assets of a partner, otherwise liable on a claim, unless the creditor has first recovered a judgment against the partnership itself and "that judgment has been returned unsatisfied in whole or in part." 15

It is clear that Lewis and Ames were aware of the formulations in the Partnership Act of 1890 , to the extent of using the statute as an interim drafting model in some respects. The 1890 statute originated with the work of Sir Frederick Pollock, who in 1879 drafted the initial bill to consolidate the law of partnership. ${ }^{16}$ Lewis recounts that although in early drafts the wording of the English statute was followed verbatim, by the end of the project it was redrafted to reduce the language "to as simple a form as possible." 17 Lewis takes particular authorial pride in having reduced, to twelve lines, the Partnership Act's one-page treatment of when a recipient of a share in profits is not a partner. ${ }^{18}$

\section{THE MAJOR DISPARITY}

Against this background, it is significant that the U.S. legislation departed from the 1890 Act in one basic respect, a divergence that continues in RUPA. Under the Partnership Act of 1890 , as under the U.S. legislation, a general partnership is a relatively fragile form of business association because there are many circumstances that will cause a partnership to dissolve. These circumstances include the death of an individual partner and an agreement among partners to dissolve. ${ }^{19}$

work out in a satisfactory way the rights of a firm creditor against the separate property of a partner." $I d$. at 640 . Lewis additionally argued that treating partnerships as entities would entail the creation of a system of registration. See id. at 641 . However, RUPA, which treats partnerships as entities, does not require registration. See REV. UNIF. P'SHIP ACT $\S 201$ (a) (amended 1997), 6 U.L.A. 55 (Supp. 2001) (stating that a partnership is an entity distinct from its members).

15. REV. UNIF. P'SHIP ACT $\S$ 307(d) (amended 1997), 6 U.L.A. 73 (Supp. 2001). Comparable legislation in some states preceded RUPA. See, e.g., Security Bank v. McCoy, 361 N.W.2d 514 (Neb. 1985) (applying NEB. REv. STAT. § 25-316 (1985)); see also LAW COMM’N \& SCOTTISH LAW COMM’N, supra note 1, at 137-40 (proposing alternate reform in which partnership's liability is primary and that of individual partners is secondary). Under RUPA, a creditor may not satisfy a judgment against a partnership from the individual assets of a partner unless the creditor has also obtained a judgment against that partner. REV. UNIF. P'SHIP ACT $\S$ 307.(c) (amended 1997), 6 U.L.A. 73 (Supp. 2001). In contrast, one of the Law Commission's proposals is that a creditor be permitted to enforce a judgment against a partnership directly against a partner's assets without obtaining a judgment against that partner. See LAW COMM'N \& SCOTTISH LAW COMM'N, supra note 1, at 140.

16. See R.C. I'ANSON BANKS, LINDLEY \& BANKS ON PARTNERSHIP 4 (17th ed. 1995). In 1865, legislation known as "Bovill's Act" clarified distinctions between partnership and various forms of debtor-creditor relationships. Sections 2 and 3 of the Partnerhsip Act of 1890 contain the substance of Bovill's Act. See MORSE, supra note 9, at 36 . For a discussion of how best to characterize partnership legislation, see infra text accompanying notes $36-40$.

17. See Lewis, supra note 11 , at 621 .

18. See id. (comparing section 2 of the Partnership Act of 1890 with section 7 of the UPA).

19. Partnership Act, 1890,53 \& 54 Vict., c. 39, $\S \S 32-35$ (Eng.) (stating circumstances under which dissolution will occur); UNIF. P'SHIP ACT \$29 (1914), 6 U.L.A. 752 (1995) (defining dissolution as "the change in the relation of the partners caused by any partner ceasing to be associated in the carrying on as distinguished from the winding up of the business"); id. $\S \S 31-32,6$ U.L.A. $771-883$ (1995) (stating causes of dissolution and when dissolution may be ordered by a court). 
Dissolution is a complex idea and body of doctrine. Its basic effect is to terminate the association among partners, which creates a right in individual partners to their share (net of claims owing to third parties and to other partners) of partnership property. ${ }^{20}$ Partners who wish to carry on post-dissolution may do so by forming a new partnership, but the claims incident to settling-up may erect practical obstacles to this course. ${ }^{21}$

The intriguing difference among statutes is the effect each gives to a partner's stated intention or will to dissolve when no other ground for dissolution is present. Section 32 of the Partnership Act of 1890 provides that such notice is effective to dissolve a partnership when it has been entered into for an undefined term. ${ }^{22}$ In contrast, a partner's notice of intention to dissolve is ineffective when a partnership has been formed for a fixed term and that term has not yet expired, or when the partnership has been formed for a specific undertaking that has not yet been completed. ${ }^{23}$ In a partnership that is not a partnership at will, an agreement among partners is a requisite for dissolution unless some other circumstance causes dissolution. Further, a partner's notice to third parties that the partner shall no longer be bound by co-partners' acts is not operative when the notice is ineffective to dissolve the partnership. ${ }^{24}$ In contrast, under section $31(2)$ of the UPA, an individual partner's express will to dissolve effects dissolution when no other circumstance permits dissolution. ${ }^{25}$ This is true even when the dissolution contravenes a provision in the partnership agreement, as in a partnership for a fixed term or the completion of a specific project. 26

Moreover, this basic difference persists in RUPA. The drafters of RUPA were concerned with developing terminology that distinguished between a partner's departure from the firm and the "various aspects of the process of disengagement from the relationship." 27 A partner who departs from the firm "disassociates" under RUPA. ${ }^{28}$ "Dissolution" follows only when the partnership's business is wound-up. Although RUPA's consequences are not identical to those created by the UPA in all respects, a partner has the power to disassociate at any time by giving express notice that the partner

20. See UNIF. P'SHIP ACT $\S 38(1)$ (1914), 6 U.L.A. 880 (1995); REV. UNIF. P'SHIP ACT $\S 807(b)$ (amended 1997), 6 U.L.A. 118-19 (Supp. 2001). The relationship between these rights and provisions in the partnership agreement is discussed infra text accompanying notes 60-61.

21. For example, the partners who wish to continue the business in a newly-formed partnership may be unable to fund the purchase of the old partnership's assets.

22. Cases have defined a partnership with no fixed term to include a partnership in which partners have agreed that no dissolution may occur except by mutual agreement. See Moss v. Elphick, 1 K.B. 846 (1910). In effect, any agreement that limits a partner's right to dissolve by giving notice creates a partnership for a fixed term. See MORSE, supra note 9, at 32-33. It is open to debate whether such an agreement exists. See id. at 33.

23. Partnership Act, 1890,53 \& 54 Vict., c. 39, § 32(a)-(b) (Eng.).

24. See BANKS, supra note 16, at 393-94 (noting that the Partnership Act itself is silent on whether a partner may unilaterally revoke the authority of a co-partner). Giving notice of a purported revocation may constitute a repudiatory breach of the partnership agreement, which would entitle the innocent partners to choose whether to affirm the agreement or treat the partnership as ended. Id. at 697 . The effect of repudiation is discussed further infra notes 34-35.

25. See UNIF. P'SHIP ACT § 31(2) (1914), 6 U.L.A. 771 (1995).

26. Id.

27. Donald J. Weidner \& John W. Larson, The Revised Uniform Partnership Act: The Reporters' Overview, 49 BuS. LAW. 1, 7 (1993).

28. See ReV. UNIF. P'SHIP ACT $\S 601$ (amended 1997), 6 U.L.A. 94 (Supp. 2001). 
so intends, even when the dissolution is wrongful because it breaches a provision of the partnership agreement. 29

These basic differences illustrate the intellectual linkages between partnership, on the one hand, and concepts and doctrines drawn from the common law and the tensions among them on the other. The choice made by the Partnership Act of 1890 reflects the dominance of contract. ${ }^{30}$ Partners lack the power to dissolve in contravention of their agreement as a consequence of the contract made at the formation of the partnership. As a result, relationships among partners, third parties, and partnership property should be more stable. Third parties that deal with the partnership are assured that the group that comprises the partnership will remain members consistent with the terms of the agreement, barring an occurrence like a partner's death. They are also assured that, although many circumstances may diminish the value of partnership assets, a partner's wrongful dissociation will not be such a circumstance.

This stability should be of benefit to partners as well. Fellow partners are assured that a colleague may not leave the partnership simply by expressing the intention that it dissolve. This in turn provides an assurance of ongoing association. Moreover, fellow partners should benefit from stability even though a court will not grant an order of specific performance compelling an unwilling partner to continue to provide services to a partnership. ${ }^{31}$ If partners are unable to dissolve a partnership in contravention of their agreement, individual partners lose the ability to safeguard their individual resources against obligations that the partnership may incur following their departure from the firm. This is a reievant consideration given the joint and several nature of partners' individual liability. ${ }^{32}$ That is, it is in all the partners' best interests to know that the individual assets of their fellow partners will remain available throughout the duration of the partnership and as against the liabilities that may ensue thereafter. Nonetheless, this assurance is not complete under the Partnership Act of 1890 because a partnership may dissolve, for example, as a consequence of a partner's death or bankruptcy. In any event, the Law Commission's reform proposals are consistent with this point and, as discussed below, develop the underlying point further than does the 1890 statute. $^{33}$

29. Id. § 601(1), 6 U.L.A. 94 (Supp. 2001); id. § 602(a) (amended 1997), 6 U.L.A. 77 (1995).

30. Commentators on English partnership law emphasize its contractual nature. See, e.g., MORSE, supra note 9 , at 4.

31. See C. H. Giles \& Co., Ltd. v. Morris, [1972] I W.L.R. 307, 317-19 (Ch. 1971) (discussing the bases for judicial reluctance to grant specific enforcement of contract involving more than a minor element of personal services or continuous personal services); RESTATEMENT (SECOND) OF CONTRACTS $§ 367(1)$ (1981) (stating that promise to render personal services will not be specifically enforced); id. cmt. b (discussing the definition of personal service); see also BANKS, supra note 16, at 617-18 nn.39-42 (stating that court would not decree specific performance of agreement for partnership at will, nor would court decree specific performance of agreement to perform personal services); Robert W. Hillman, Indissoluble Partnerships, 37 U. FLA. L. REV. 691,733 (1985) (noting that "although a court will not compel an individual to perform services on behalf of another... limitations on the availability of specific performance do not require the free dissolvability of partnerships" because a partner's involvement in a partnership may take a form other than provision of services).

32. See Partnership Act, 1890, 53 \& 54 Vict., c. 39, §§ 9, 12 (Eng.).

33. The Consultation Paper specifically considers whether "a partner in a partnership of defined duration should have a right to withdraw" when the partnership agreement itself does not confer such a right. It provisionally rejects this possibility because "[t]he partners will have contracted to be in the partnership for a 
Another implication of the dominance accorded to a contract is that a partner's repudiation of the partnership contract should not terminate the contract and convert the partnership into one at will. If the innocent partners wish to dissolve following the repudiation, some other route toward dissolution should be identified, such as an agreement among the partners or an application to the court for an order dissolving the partnership. ${ }^{34}$ Otherwise, if a partner repudiates the partnership contract, partners who wish to continue the partnership are denied the financial stability for which they contracted originally, if risk averse partners may exit freely in the wake of the partner who initially repudiated the contract. 35

To be sure, one might wonder how comprehensively a partnership statute should be understood to control the resolution of partnership-related disputes and whether the statute ousts the applicability of common-law doctrines completely or only partially. A full answer to this difficult question is beyond the modest scope of this Article. As points of departure, though, one might consider the nature of partnership legislation and how the legislation itself addresses the possible applicability of other bodies of law. The Partnership Act of 1890 has been characterized as substantially "declaratory" in nature because its intention was largely to restate principles already developed in common-law and equity cases. ${ }^{36}$ Although the UPA largely restates preceding law, in some respects it also reflects more choice among competing rules because its drafters considered and resolved points of doctrinal divergence among states. ${ }^{37}$ Both statutes expressly contemplate that other bodies of law may be applicable to partnerships. The Partnership Act of 1890 preserves in section 46 " [ $t$ ]he rules of equity and common law applicable to partnership ... except so far as they are inconsistent with the express provisions of this Act." 38 The UPA provides that "[i]n any case not provided for in this act, the rules of law and equity, including the law merchant, shall govern." 39 RUPA provides that "[u]nless displaced by particular provisions of this [Act], the principles of law and equity supplement" the Act. ${ }^{40}$ These formulations are not identical; the standard in the Partnership Act of 1890 is inconsistency, compared with whether a case is "provided for" in the UPA, and whether legal principle is "displaced" by RUPA. Of the three formulations, the inconsistency standard in the Partnership Act of 1890 is arguably the friendliest to applying extra-statutory law. In contrast, the UPA may contain provisions that can be interpreted to "provide for" a case by generating a rule for decision by analogy or by extension.

defined term; the law should respect that contract." LAW COMM'N \& SCOTTISH LAW COMM'N, supra note 1, at 66.

34. See id. at 70. This argument is contrary to the dictum in Hurst v. Bryk. [2000] 2 W.L.R. 740, 746-50 (H.L.) (stating that a repudiatory breach terminates the partnership contract). The dictum continues, however, with the reservation that the termination of the partnership contract does not automatically dissolve the partnership because the equitable jurisdiction of the court to decree dissolution should not be circumvented. Id.

35. If a partner wrongfully repudiates a partnership agreement, fellow partners no longer owe fiduciary duties to the partner who repudiated. See MORSE, supra note 9, at 111-12.

36. See id. at 3-4.

37. See Lewis, supra note 11 , at 623 . However, the dearth of precedent in many states and confusion in legal theory were more important causes of confusion in the common law of partnership in the United States. Id.

38. Partnership Act, 1890,53 \& 54 Vict., c. $39, \S 46$ (Eng.).

39. UNIF. P'SHIP ACT $\S 5$ (1914), 6 U.L.A. 254 (1995).

40. REV. UNIF. P'SHIP ACT § 104(a) (amended 1997), 6 U.L.A. 47 (Supp. 2001). 
In any event, one might accord controlling effect to the statute on matters that it addresses explicitly or by ready implication. These include the causes of dissolution, which partnership legislation itself specifies. It is inconsistent with statutory specification of the circumstances that cause dissolution to import an additional cause by applying common-law contract doctrines, such as anticipatory repudiation.

In contrast with its English counterpart, partnership legislation in the United States assigns dominance to the agency elements in partnership. As noted above, all partners are the firm's agents, and when a partner's act binds the partnership, it creates individual liability for all partners. A defining element in the common law of agency, in England as well as the United States, is the power held by both principal and agent to terminate an agent's actual authority. The principal terminates by revoking authority, while the agent terminates by renouncing it. ${ }^{41}$ From the standpoint of a principal, the power to revoke authority is a basic measure to control the agent and self-protect against the risks present in a relationship in which another person's actions carry direct legal consequences for oneself. From the standpoint of an agent, the power to renounce authority enables the agent to move on to other activities and associations. The common law of agency recognizes the effect of revocation and renunciation even when they contravene a contract between principal and agent. The effect is to empower principal and agent to act on assessments of risk and self-interest that occur subsequent to an initial agreement between them.

In commenting on the 1914 uniform legislation as its drafter, Lewis wrote simply and declaratively that, "[t]he relation of partners is one of agency. The agency is such a personal one that equity cannot enforce it even where the agreement provides that the partnership shall continue for a definite time." 42 Lewis also noted that uncertainty on the point had preceded the statute's resolution and that "[t]he English law is opposed to this view." 43 The practical insights in the partnership context are that the ability to exit from the partnership is relevant to downside scenarios as well as upside scenarios. On the downside, the ability to exit at any time enables a partner to cut off the risk stemming from post-dissolution liabilities, at least once third parties have notice that the partner has left the firm. On the upside, having left the partnership, the former partner no longer owes fiduciary duties to former colleagues (excepting duties that follow the possession of confidential information) and, subject to contractual restraints, is free to compete and pursue opportunities that would otherwise fall within the partnership's ambit. In contrast, a contract-dominated view binds parties more tightly to their initial assessments of risk and self-interest.

41. See RESTATEMENT (THIRD) OF AGENCY $\S 3.10(1)$ (Tentative Draft No. 2, 2001); see generally Francis Reynolds, When is an Agent's Authority Irrevocable?, in MAKING COMMERCIAL LAW: ESSAYS IN HONOUR OF ROY GOODE 259 (Ross Cranston ed., 1997).

42. See Lewis, supra note 11 , at 628 . This passage continues: "The power of any partner to terminate the relation, even though [in] doing so he breaks a contract, should, it is submitted, be recognized." Id.

43. Id. at 627 n.8. 


\section{Mitigating ElEMENTS}

\section{A. United States}

This Article has characterized the difference between general partnership law in the United States and England as involving an "architectural" feature of partnership law, a basic design choice that carries many corollary consequences. ${ }^{44}$ Either choice has the potential to create harsh consequences, which various provisions in each statute may mitigate. Consider first the consequences of the agency-dominated design of the U.S. legislation. If a partner has power to dissolve at any time in contravention of the partnership agreement, the partner might use the power, or threaten to use it, when fellow partners will be unable to carry on the partnership's business. Upon dissolution, a partner has the right to receive that partner's share of partnership assets, minus the partner's share of liabilities. ${ }^{45}$ Partners who wish to carry on the business may be unable to raise the cash requisite to buy out the share of the partner who has dissolved. This prospect may create leverage in bargaining for opportunistic partners who threaten to dissolve unless fellow partners agree to sweeten the terms of the partnership agreement to the benefit of the partner who threatens dissolution. This consequence follows because the structure of partnership law also draws on property concepts by specifying circumstances under which a partner may compel the sale or division of partnership assets to complete a winding-up. 46 A partner's premature withdrawal may also damage the partnership by reducing the willingness of third parties to deal with the shrunken firm or by leading third parties to demand better terms to induce them to deal.

Accordingly, both the UPA and RUPA contain provisions that reduce the risks that wrongful dissolution and dissociation would otherwise impose on fellow partners. Under both statutes, partners who have not wrongfully dissolved or dissociated have a claim against their now-former partner for damages caused by the dissolution or dissociation, which is to be subtracted from the now-former partner's account. ${ }^{47}$ Additionally, some courts developed doctrines of bad-faith dissolution or dissolution in contravention of a partner's fiduciary duty. The leading case, Page v. Page, held that a partner's power to dissolve a partnership, "like any power held by a fiduciary, must be exercised in good

44. See supra Part I.

45. See UNIF. P'SHIP ACT § 38(1) (1914), 6 U.L.A. 880 (1995); REV. UNIF. P'SHIP ACT $\S 807(b)$ (amended 1997), 6 U.L.A. 118-19 (Supp. 2001). The relationship between these rights and provisions in the partnership agreement is discussed infra in text accompanying notes 60-61.

46. In this respect general partnership shares some of the instabilities of tenancies in common. In U.S. law, a tenancy in common carries the risk that a co-owner will seek a partition by sale, which will oust the other coowners unless they purchase the property. For an extended treatment of this problem and its more general implications, see generally Hanoch Dagan \& Michael Heller, The Liberal Commons, 110 YALE L.J. 549 (2001).

47. See UNIF. P'SHIP ACT § 38(2)(a)(II), (c)(II) (1914), 6 U.L.A. 880-81 (1995); REV. UNIF. P'SHIP ACT § 602(c) (amended 1997), 6 U.L.A. 98 (Supp. 2001). RUPA is a bit kinder to partners who wrongfully dissociate because it does not exclude partnership goodwill in calculating the value of the wrongfully dissociated partner's partnership interest. Under RUPA, if the partnership's goodwill is damaged by the wrongful dissociation, the amount of damage is offset against the buyout price received by the wrongfully dissociated partner. Compare UNIF. P'SHIP ACT $\S 38(2)$ (c)(II) (1914), 6 U.L.A. 881 (1995), with REV. UNIF. P'SHIP ACT $\$ \S 602$ (c) \& cmt. 3, 6 U.L.A. 98 (1995), and id. $§ 701 \mathrm{cmt} .3$ (1994), 6 U.L.A. 102 (1995). 
faith."48 RUPA does not explicitly address whether a partner's power to dissociate is subject to a good-faith or fiduciary-duty limit. ${ }^{49}$ Both RUPA and the UPA enable partners who have not wrongfully dissolved or dissociated to continue to use partnership property to operate the business. Both also permit the deferral of payment to the partner who wrongfully dissolved or dissociated, until the partnership's term has expired. ${ }^{50}$ This right is conditioned on securing payment of the former partner's share. ${ }^{51}$ RUPA is more friendly to continuation because it provides that, following a partner's wrongful dissociation, winding-up of partnership business will occur only if it is the express will, determined within ninety days following the dissociation, of at least half of the remaining partners. ${ }^{52}$ As a result, if a majority of the remaining partners so wish, they may continue the partnership's business. However, the partnership agreement may eliminate this possibility. As the statute is structured, continuation by the majority of remaining partners is the default rule, subject to ouster by contrary provision in the partnership agreement. ${ }^{53}$ In contrast, the partnership agreement may not oust the statutory provisions that govern dissolution by court order or on the basis that carrying on the partnership has become illegal. 54

Even with these mitigating elements, U.S. partnership legislation has been criticized for its unwillingness to bind partners to the terms of their agreement. However, the critics disagree about the preferable alternative. Professors Bromberg and Ribstein would make a partnership agreement that explicitly limits a partner's power to dissociate specifically enforceable. ${ }^{55}$ In contrast, Professor Hillman would treat a partnership as indissoluble when the partnership agreement specifies a particular term or undertaking, which is

48. 359 P.2d 41, 44 (Cal. 1961).

49. REv. UNIF. P'SHIP ACT § 404(d) (amended 1997), 6 U.L.A. 83 (Supp. 2001) (imposing a duty of good faith and fair dealing on partners in exercising rights and discharging duties to the partnership and to fellow partners). The facts of Page itself are unlikely to trigger the good-faith duty imposed by section 404(d). In Page, the partner who sought dissolution was also a creditor, and the attempted dissolution occurred when the partnership's business took a tum for the better, but the amount of debt owing to that partner made it unlikely that a third party would buy the partnership's assets. RUPA section 404(f) provides that a partner may "lend money to and transact business with the partnership, and as to each loan or transaction the rights and obligations of the partner are the same as those of a person who is not a partner, subject to other applicable law." REV. UNIF. P'SHIP ACT $\$ 404$ (f) (amended 1997), 6 U.L.A. 83 (Supp. 2001).

50. See UNIF. P'SHIP ACT $\S \S 38(2)$ (b), (c)(II) (1914), 6 U.L.A. 881 (1995); REV. UNIF. P'SHIP ACT $\S$ 701(h), 801(2)(ii) (amended 1997), 6 U.L.A. 101, 108 (Supp. 2001). Under section 38(2)(b), whether a partnership's business continues in the wake of a wrongful dissolution depends on whether all the remaining partners "desire to continue the business in the same name, either by themselves or jointly with others." UNIF. P'SHIP ACT $\S 38(2)(b)$ (1914), 6 U.L.A. 881 (1995). Under RUPA section 801(2)(i), the business may continue unless at least half of the remaining partners expressly wish to wind-up. REV. UNIF. P'SHIP ACT $\S 801(2)(\mathrm{i})$ (amended 1997), 6 U.L.A. 108 (Supp. 2001).

51. See UNIF. P'SHIP ACT $\S 38(2)(c)(I I)(1914), 6$ U.L.A. 881 (1995); REV. UNIF. P'SHIP ACT $\S 701$ (h) (amended 1997), 6 U.L.A. 101 (Supp. 2001).

52. REV. UNIF. P'SHIP ACT § 801(2)(i) (amended 1997), 6 U.L.A. 108 (Supp. 2001). A partner who dissociates within ninety days after another partner's wrongful dissociation does so rightfully. See id. $\S$ 602(b)(2)(i) (amended 1997), 6 U.L.A. 98 (Supp. 2001). The rightful dissociation is treated as an expression of will to wind up partnership business. See id. $\S 801$ (2)(i) (amended 1997), 6 U.L.A. 108 (Supp. 2001).

53. See REV. UNIF. P'SHIP ACT $\S 103$ (amended 1997), 6 U.L.A. $44-45$ (Supp. 2001).

54. See id. $\S 103$ (b)(8), 6 U.L.A. 44-45 (Supp. 2001).

55. See ALAN R. BROMBERG \& LARRY E. RIBSTEIN, BROMBERG AND RIBSTEIN ON PARTNERSHIP $\S$ 7.03(d), at 7:60, n.23 (Supp. 1999-2). 
consistent with the Partnership Act of 1890.56 All agree on an underlying premise that in negotiating the terms of their prospective association as partners, parties should be permitted to strike a binding agreement that reflects each party's relative assessment of the risks that the partnership will create and the benefits of assuring greater stability in the association. 57

This underlying premise is, however, open to question if the risks created by the agency that the partnership creates are more difficult than other business risks to assess at the point of an initial agreement or if these risks are especially problematic in some other way. The demographics of partnership are also relevant. In particular, reflecting its status as the default form of organizational choice, general partnership law is applicable to business associations in which parties may lack the sophistication to strike a closelytailored bargain reflecting a balance among risks and opportunities as perceived by each participant, even following careful analysis and professional counsel. For example, English authorities report that, at present, at least half of all partnerships have no comprehensive partnership agreement. ${ }^{58}$ This constituency may include members not readily able to assess the risks created by operating a business as a general partnership. In addition, these members are unlikely to obtain sophisticated professional assistance to evaluate these risks so that they may be assessed in relation to benefits anticipated in a structure that binds partners to membership on stated terms.

Another way to characterize U.S. partnership law is that it limits the extent to which partners may use pre-commitment strategies to reduce the risk of subsequent defections. A pre-commitment strategy consists of a person's voluntary actions that restrict future options when the person realizes that her preferences may differ in the future from her preferences at the time of committing. Pre-commitment may be rational when one anticipates greater benefit from credibly committing to stay a particular course, despite subsequent changes in preferences. For example, Ulysses pre-committed to staying his navigational course and to sailing past the Sirens when he directed his crew to bind him to the mast and to stop their ears against the Sirens' song. ${ }^{59}$ The statutory power to dissolve is, of course, antithetical to pre-commitment.

As it happens, an additional limit on pre-commitment comes from general contract law. Suppose a partnership agreement provided that a partner who wrongfully dissolved the partnership or dissociated from it would lose any right to any subsequent payment from the partnership, including the return of the partner's capital account and any share of profits to which the partner would otherwise be entitled. Such a provision is enforceable only if it can be characterized as a reasonable estimate of damage that the

56. See Hillman, supra note 31 , at 735.

57. See id. at 731; BROMBERG \& RIBSTEIN, supra note 55, at 7:59-:60.

58. See Elspeth Deards, Partnership Law in the Twenty-First Century, J. BuS. L., July 2001, at 357, 362.

59. See JON ELSTER, UlySSES AND THE SIRENS: STUdIES IN RATIONALITY AND IRRATIONALITY 36-47 (1979). Sometimes a pre-commitment strategy is not the wisest course. Ulysses would regret his crew's compliance with his instructions if, once past the Sirens, he sighted a sea monster but was unable-the crew's ears still being stopped-- to warn them of the impending peril of being swallowed by the monster if the ship does not change course. Likewise, if Ulysses misunderstands the risk that the Sirens pose, his pre-commitment strategy may not be wise. For these points, see James Herbie Difonzo, Customized Marriage, 75 IND. L.J. 875, 945 (2000). 
partnership will incur, as opposed to a penalty. ${ }^{60}$ Thus, contract law itself limits the extent to which a partnership agreement may be structured to deter defections. Additionally, many cases testing the limits of such provisions involve contests between a partnership's remaining members and former partners engaged in competitive activities. ${ }^{61}$ Contract law does not enforce promises that restrain competition if they are "unreasonable," a determination that considers whether the restraint is necessary to protect the promisee's legitimate interests, whether it will result in hardship to the promisor, and whether it is likely to injure the public. ${ }^{62}$ These factors range beyond partners' determinations of the advantage they mutually anticipate at the time they structure their partnership agreement.

\section{B. England}

Similarly, the English legislation contains provisions that reduce the risks created by the contract-dominated design choice. There are several grounds on which a partner may petition the court for a decree of dissolution, including another partner's conduct that prejudicially affects partnership business and, more generally, circumstances that make it "just and equitable" that the partnership be dissolved. ${ }^{63}$ To be sure, U.S. legislation states similar bases on which a court may order dissolution or dissociation. ${ }^{64}$ Additionally, in both England and the U.S., dissolution occurs automatically upon the occurrence of a partner's death or bankruptcy unless the partnership agreement otherwise provides. ${ }^{65}$ If the other partners wish, a partnership may be dissolved if a partner's share becomes subject to a creditor's charging order. ${ }^{66}$ An unhappy partner in an English partnership may thus benefit if dissolution occurs fortuitously, for example as a consequence of a fellow partner's death or bankruptcy, because the partnership association then ends but the unhappy partner has not repudiated the partnership agreement.

Moreover, this perspective provides a framework for explaining why, with the exception of certain professional firms, English partnerships are illegal if they have more than twenty partners. ${ }^{67}$ Exceeding this number automatically dissolves the partnership on

60. See Howard v. Babcock, 863 P.2d 150, 151 (Cal. 1993) (holding that provision in partnership agreement stating that partner would forfeit some or all rights to benefits upon withdrawal if partner entered into competition with partnership was enforceable; the provision took only a "reasonable toll" on departing partners who competed, and represented a reasonable attempt by the partnership to estimate damages from the loss as opposed to an unenforceable penalty); Meehan v. Shaughnessy, 535 N.E.2d 1255, 1266 (Mass. 1989) (holding that partnership could not retain former partners' capital accounts and profit shares; capital contributions and profit shares "are not a form of liquidated damages to which partners can resort in the event of a breach" of the partnership agreement).

61. See BROMBERG \& RIBSTEIN, supra note 55, $\S 7.12$ (b)(2), at 7:178-:179 (Supp. 2001-1).

62. RESTATEMENT (SECOND) OF CONTRACTS $§ 188(1)$ (1981).

63. See Partnership Act, 1890,53 \& 54 Vict., c. $39, \S 35$ (Eng.).

64. See UNIF. P'SHIP ACT $\$ 32$ (1914), 6 U.L.A. 804 (1995); REV. UNIF. P'SHIP ACT $§ 601$ (5) (amended 1997), 6 U.L.A. 94 (Supp. 2001).

65. See Partnership Act, 1890,53 \& 54 Vict., c. 39, § 33(1) (Eng.).

66. See id. § 33(2); REV. UNIF. P'SHIP ACT § 601(4)(ii) (amended 1997), 6 U.L.A. 94 (Supp. 2001) (partner may be dissociated following unanimous vote to expel if partner's transferable interest in partnership has become subject to charging order that has not been foreclosed).

67. See LAW COMM'N \& SCOTTISH LAW COMM'N, supra note 1, at 56 (citing sections 716 and 717 of the Companies Act of 1985 with regard to excepting firms of solicitors, accountants, and stockbrokers; also citing section 4(2) of the Limited Partnership Act of 1907, with regard to limited partnerships). 
the basis of illegality. ${ }^{68}$ This limitation is difficult to justify, especially in a framework largely dominated by contract, making it unsurprising that the Law Commission's Consultation Paper identifies the size limit as an obvious target for abolition. ${ }^{69}$ The limitation may be explained, but not justified, by the risks created by a binding contractual undertaking that makes one individually liable on the basis of others' actions. One might sensibly proceed with caution before making such a commitment and might in particular wish to have ample information about prospective fellow partners. The statutory limit may represent a rough proxy for circumstances under which the cautious would decide to proceed. However, this does not suffice as a justification for a mandatory size limit: Individuals' preferences for undertaking risk vary, as do the risks a particular business typically entails and the information available with which to assess risk.

\section{FURTHER IMPLICATIONS}

These underlying differences in general partnership law have implications outside the realm of partnership. In the United States, business associates who wish to avoid the instability of general partnership have many choices, including the long-standing choices of incorporating the business or organizing as a limited partnership. An innovation of the last couple of decades, limited liability companies (LLCs) are organized under statutes that permit, like partnership, great organizational flexibility without the risk of individual liability for LLC members. Although the statutes governing these forms differ, none creates a power of dissolution or dissociation with the consequences that affect the stability of a general partnership. ${ }^{70}$ In this context, it is possible to understand the general partnership as a "penalty default." 71 That is, many, if not most, organizers of business firms may prefer characteristics that cannot be achieved through a general partnership; the structure of general partnership law creates incentives to choose other organizational forms. In contrast, in England, where the statute permits the formation of general partnerships with greater stability, the incentive to look elsewhere for alternate organizational choices may be weaker, as may be legislative incentives to produce them. English authorities report that almost forty percent of businesses with more than one

68. See Partnership Act, 1890,53 \& 54 Vict., c. $39, \S 34$ (Eng.).

69. See LAW COMM'N \& SCOTTISH LAW COMM'N, supra note 1, at 56-59.

70. See, e.g., DEL. CODE ANN. tit. 8, $\S 275$ (2000) (stating the procedure for dissolution of business corporations, initiated by resolution adopted by corporations' directors and approved by vote of majority of shares having the right to vote); UNIF. LTD. P'SHIP ACT $\S 801$ (1976), 6A U.L.A. 240 (1995) (limited partnership is dissolved as specified in its certificate or in limited partnership agreement; upon written consent of all partners; or upon withdrawal of a general partner unless partnership has another general partner and partnership agreement permits partnership business to be carried on by remaining general partner, or unless within ninety days of withdrawal all partners agree in writing to continue and to appointment of one or more general partners if necessary or desired); DEL. CODE ANN. tit. 6, $\$ 18-801$ (2000) (stating that an LLC is dissolved as specified in LLC agreement; unless agreement provides otherwise, affirmative vote of two-thirds of members effective to dissolve LLC).

71. This term was formally defined in the landmark article by Ian Ayres and Robert Gertner. Ian Ayres \& Robert Gertner, Filling the Gaps in Incomplete Contracts: An Economic Theory of Default Rules, 99 YALE L.J. 87 (1989). 
owner choose to be partnerships, which may reflect either a good fit between partnership law and the needs of its users or the lack of better-fitting alternatives. ${ }^{72}$

These basic differences may have further implications for other comparisons that could be made. For example, are partners' fiduciary duties defined more broadly and enforced more stringently in fixed-duration English partnerships than in partnerships governed by U.S. law? Partners who are more firmly bound to each other by their prior agreement may be more vulnerable to various forms of opportunistic and self-serving conduct by fellow partners. It is noteworthy that the Law Commission's comprehensive review of English partnership law does not propose any material change in partners' fiduciary duties, including any articulation of the extent to which those duties may be reduced by provisions in a partnership agreement. ${ }^{73}$ The Law Commission proposes, however, the addition of a statutory statement of a duty of good faith and fair dealing. ${ }^{74}$ In contrast, RUPA section 404(b) limits fiduciary duties to those explicitly stated in the Act. ${ }^{75}$ While section 103 (a) explicitly provides that the partnership agreement shall govern partners' relations with each other, section 103(b) provides that an agreement may not eliminate partners' fiduciary duty of loyalty. ${ }^{76}$ Additionally, the Law Commission's review does not propose any material revisions to the mandatory duty imposed on each partner by section 28 of the Partnership Act of 1890 to "render true accounts and full information of all things affecting the partnership to any partner or his legal representatives."77 RUPA, in contrast, permits a partnership agreement to restrict a partner's right of access to partnership books and records so long as the restriction is not unreasonable. ${ }^{78}$ RUPA also appears to permit a partnership agreement to eliminate the duty imposed on each partner and the partnership by section 403(c)(1) to furnish "without demand, any information concerning the partnership's business and affairs reasonably

72. See Deards, supra note 58, at 375. Aggregate data on the number of partnerships in the United States does not always distinguish among all firms that file a partnership tax retum-some of which are LLCs-and firms that are organized as partnerships. For example, according to the 2000 edition of the Statistical Abstract of the United States, in 1997, active "partnerships" numbered 1,759,000 with approximately $\$ 1.3$ trillion in business receipts. U.S. BUREAU OF THE CENSUS, STATISTICAL ABSTRACT OF THE UNITED STATES tbl. 858 (2000). However, inclusion in the "partnership" category is based on tax-filing status, and thus may include firms organized as LLCs. In the same period, 4,710,000 corporate tax returns were filed, including 2,452,000 filed by subchapter $\mathrm{S}$ corporations. Id. tbl. 862 . Total corporate receipts amounted to approximately $\$ 16.6$ trillion. Id.

Data derived from partnership tax returns, which ask whether the filer is organized as an LLC or a partnership, illustrate that the number of LLCs has increased rapidly. In 1998, 470,657 LLCs filed a partnership tax return, up from 349,054 in 1997 and 221,498 in 1996. Alan Zempel, Partnership Returns, 1998, at 69, in INTERNAL REVENUE SERVICE, Statistics of INCOME BUlletin, Fall 2000 (on file with The Joumal of Corporation Law). In 1998, the number of LLCs exceeded the number of limited partnerships. Id. Like most partnerships, most LLCs operate in the finance, insurance, real estate, rental and leasing and services sectors. Id. The significance of partnerships in these sectors is a long-established trend. Id. at 62. In 1998, LLCs reported $\$ 1.2$ trillion in total assets, which represents $23.2 \%$ of total assets reported by all partnerships. Id. at 69 . In all industries in 1998, businesses that filed partnership tax returns reported total receipts of $\$ 1.8$ trillion. Id. at 67.

73. See LAW COMM'N \& SCOTTISH LAW COMM'N, supra note 1 , at 179-85.

74. Id.

75. REV. UNIF. P'SHIP ACT $\S$ 404(b) (amended 1997), 6 U.L.A. 83 (Supp. 2001) (limiting a partner's duty of loyalty).

76. Id. $\S 103(\mathrm{a})-(\mathrm{b}), 6$ U.L.A. $44-45$.

77. Id. at 179.

78. REV. UNIF. P'SHIP ACT $\S 103($ b)(2) (1994), 6 U.L.A. 44 (1995). 
required for the proper exercise of the partner's rights and duties under the partnership agreement."79 In this respect, RUPA is consistent with a pre-RUPA case that enforces provisions in a partnership agreement that specified partners' rights to receive information when the information was material to evaluating an offer received from the managing partner to purchase their interests. ${ }^{80}$ English authority, in contrast, stresses the mandatory nature of the rights and duties created by section 28 of the Partnership Act of 1890 , even when the transactional context is the purchase by one partner of another's interest. 81

These basic differences may also carry implications for the relative extent to which particular remedies are sought. For example, in fixed-duration English partnerships, is more use made of judicial dissolution as a mechanism to allow exit from the firm? Should the standards for judicial dissolution of a corporation on "just and equitable" grounds be the same as those applicable to dissolution of a partnership? The differences between partnership and corporate structures cut in opposite directions. A general partnership's relative fragility means that more bases for exit may be available, in contrast with the relative durability of a corporation. However, membership in a general partnership, unlike shareholding, creates an ongoing risk of individual liability for business obligations. 82

What to make of these differences in light of the recent availability, in both countries, of limited liability options for general partnerships is open to question. The Limited Liability Partnerships Act of 2000, like limited liability partnership (LLP) legislation in the United States, makes it possible for two or more persons associated as partners to register as a limited liability partnership. Eligibility for English LLP status is not limited to professional services partnerships, although their concern about the risk of increasing liability on claims of negligence led to the legislation. ${ }^{83}$ Eliminating individual partners' risk of liability to third parties for partnership obligations should significantly reduce the unattractiveness of enforcing partnership agreements that bind partners to each other for a fixed term. However, that risk remains present for partners who do not register their partnership as an LLP, in particular the less sophisticated cohorts within the realm of partnership. Partnerships that operate without a comprehensive written partnership agreement-as at least half of English partnerships reportedly do ${ }^{84}$-may be unlikely to register as an LLP, unless the newly-available prospect of limited liability spurs an increase in the requisite attention to organizational formality.

79. See id. $\S 403(\mathrm{c})(1), 6$ U.L.A. 81 (1995). Section 403(c)(1) is not explicitly insulated by section 103(b) from the effects of contrary provisions in the partnership agreement.

80. See Exxon Corp. v. Burglin, 4 F.3d 1294, 1300 (5th Cir. 1993) (holding that the general partner did not breach the fiduciary duty owed to limited partners by purchasing limited partners' interests when partnership agreement restricted limited partners' access to information material to value of their interests but gave limited partners option of sharing the cost of independent valuation).

81. See MORSE, supra note 9, at 112-13.

82. For the point that simple analogies between partnership and corporate law can be misleading, see Frank H. EASTERBROOK \& DANIEL R. FISCHEL, THE ECONOMIC STRUCTURE OF CORPORATE LAW, 249-50 (1991).

83. See John WhitTAKER \& John MAChell, Limited Liability PARTNERShiPS: The NEW LAW, at v (2001).

84. See supra text accompanying note 58. 
Interestingly, the Law Commission's thoughtful Consultation Paper on partnership articulates a reform philosophy of enhancing the duration of partnerships. For example, under the 1890 statute, a partner's death or bankruptcy automatically dissolves the partnership unless the partnership agreement provides otherwise. ${ }^{85}$ The Consultation Paper questions whether the default should be shifted, such that a partner's death or bankruptcy would dissolve only the relationship between that partner and the others, unless the partnership agreement provides that it shall also dissolve the partnership. ${ }^{86}$ It is likely, as the Consultation Paper observes, that this change would accommodate "the presumed wishes of partners who have not provided for death or bankruptcy one way or the other in the partnership agreement," 87 especially given that any of the partners could withdraw from the partnership if the agreement does not fix a term.

However, the preceding contrast with the U.S. material suggests another perspective from which to assess the value of fortuitously occurring events that cause dissolution. Under the Partnership Act of 1890 , a fellow partner's death or bankruptcy may serve fortuitously as an escape-hatch from a partnership when the agreement binds the partners for a fixed term and the causes of unhappiness or nervousness for a would-be escapee partner do not rise to the level that would furnish grounds on which to achieve escape through court-ordered dissolution. Shifting the default permits the agreement to bind even more tightly, which serves the interests of stability. Like the contract-dominated perspective more generally, permitting an initial agreement to bind more tightly may disserve the interests of partners who have reason to regret the commitment they previously made in the partnership agreement. For good reason, contract law is generally unsympathetic to the regret that may follow a commitment. ${ }^{88}$ The general partnership, however, combines a risk of direct individual liability with a flat organizational structure that confers actual and apparent authority on all partners. It is not surprising that mature legal systems, like England and the United States, vary in how these interests and risks are resolved.

85. See Partnership Act, 1890,53 \& 54 Vict., c. 39, § 33(1) (Eng.).

86. See LAW COMM'N \& SCOTTISH LAW COMM'N, supra note 1, at 67-69.

87. Id. at 68 .

88. See generally E. Allan FARNSWORTh, CHANGING YOUR MIND: THE LAW OF REgRETTED DECISIONS (1998). See also BROMBERG \& RIBSTEN, supra note 55, § 1.02(b), at 1:25 (Supp. 1992-2) (observing that statutory dissolution provisions are useful because "at the time of formation the parties may underestimate the possibility of problems conceming breakup; negotiations over dissolution may result in disagreement that causes the relationship to founder; and working out detailed provisions takes time and requires the expensive services of an attorney"). But see Larry Ribstein, A Mid-Term Assessment of the Project to Revise the Uniform Partnership Act, 46 BuS. LAW. 111, 147 (1990) (criticizing non-waivable power to dissolve as a "whollyunjustified restriction on private ordering"). 
